\title{
First report of chick peach (Prunus persica L.) leaf spot disease caused by Didymella glomerata in China
}

\author{
Yiping Cui ${ }^{1} \cdot$ Aitian Peng ${ }^{1} \cdot$ Xiaobing Song $^{1} \cdot$ Baoping Cheng ${ }^{1} \cdot$ Jinfeng Ling ${ }^{1} \cdot$ Xia Chen $^{1}$
}

Received: 23 December 2020 / Accepted: 8 April 2021 / Published online: 22 April 2021

(c) Società Italiana di Patologia Vegetale (S.I.Pa.V.) 2021

Keywords Chick peach $\cdot$ Leaf spot disease $\cdot$ Didymella glomerata $\cdot$ China

A disease forming spots was observed on leaves of $50 \%$ of chick peach trees (Prunus persica L.) in the same orchard (17 ha) in Guangdong $\left(24^{\circ} 20^{\prime} \mathrm{N}, 114^{\circ} 38^{\prime} \mathrm{E}\right)$, China. Initially, the brown spots at the leaf tip and edges expanded, the spot center became necrotic, and fell off. Symptomatic tissues were surface-sterilized in $75 \%$ ethanol for $30 \mathrm{~s}$, $3 \% \mathrm{NaClO}$ for $1 \mathrm{~min}$, dried, and plated on potato dextrose agar (PDA). After five days, one fungus was consistently isolated from the infected leaves on PDA exhibiting whitish mycelia at first which turned dark brown after incubation of 7 days at $28{ }^{\circ} \mathrm{C}$, with firm and tenacious texture. Conidia were ellipsoid, single-celled, slightly pigmented, and $4.5 \times 1.7 \mu \mathrm{m}$ to $8.1 \times 6.2 \mu \mathrm{m}$ in size. Morphological characteristics of the isolates were similar to those of Didymella glomerata (Corda) Q. Chen \& L. Cai as described by Boerema (1993) and Chen et al. (2015). ITS1/2 rDNA and LSU rRNA were amplified and sequenced with primers ITS1/ ITS4 and LR0R/LR5 (White et al. 1990; Jayasiri et al. 2017). The ITS (MH997456) and LSU (MW850366) showed more than $99.8 \%$ sequence identity with Didymella glomerata (KX302041.1 and MK419341). Phylogenetic analysis based on ITS and LSU showed that the isolate should belong to Didymella glomerata. For pathogenicity tests, the conidial suspension of $1 \times 10^{6}$ conidia $/ \mathrm{mL}$ was sprayed onto the healthy leaves of 1 -year-old chick peach trees in a glasshouse ( $28{ }^{\circ} \mathrm{C}$ and $80 \%$ humidity), while the control trees were sprayed with sterile distilled water. Each experiment was performed three times. Brown spots on leaves appeared seven days after spraying and were similar

Aitian Peng

pengait@163.com

1 Guangdong Provincial Key Laboratory of High Technology for Plant Protection, Plant Protection Research Institute Guangdong Academy of Agricultural Sciences, Guangzhou, China to those observed in the field. D. glomerata was re-isolated from the inoculated leaves, completing the Koch's postulates. To our knowledge, this is the first report of the peach leaf spot disease caused by D. glomerata in China (Farr and Rossman 2020).

Supplementary Information The online version contains supplementary material available at https://doi.org/10.1007/s42161-021-00834-0.

\section{Declarations}

Conflict of interests There are no potential conflicts of interest, and this research is not involved with any Human Participant or Animal. All authors have approved the submission of this manuscript.

\section{References}

Boerema GH (1993) Contributions towards a monograph of Phoma (Coelomycetes)- II. Section Peyronellaea. Persoonia 15(2):197-221

Chen Q, Jiang JR, Zhang GZ, Cai L, Crous PW (2015) Resolving the Phoma enigma. Stud Mycol 82:137-217

Farr DF, Rossman AY (2020) Fungal Databases, U.S. National Fungus Collections, ARS, USDA. Retrieved December 6, 2020

Jayasiri SC, Hyde KD, Jones EBG, Jeewon R, Kang JC (2017) Taxonomy and multigene phylogenetic evaluation of novel species inBoeremia and Epicoccum with new records of Ascochyta andDidymella (Didymellaceae). Mycosphere 8(8):1080-1101

White TJ, Bruns T, Lee S, Taylor J (1990) Amplification and direct sequencing of fungal ribosomal RNA genes for phylogenetics. In: Innis MA et al (eds) PCR protocols: a guide to methods and applications. Academic Press, San Diego, pp 315-322

Publisher's note Springer Nature remains neutral with regard to jurisdictional claims in published maps and institutional affiliations. 